\title{
Behavioral and hormonal pattern of repeat breeder cows around estrus
}

\author{
P Sood $^{1,2}$, M Zachut $^{1}, \mathrm{H}_{\text {Dube }}{ }^{1}$ and $\cup$ Moallem $^{1}$ \\ ${ }^{1}$ Department of Ruminant Science, Institute of Animal Sciences, The Volcani Center, PO Box 6, Bet-Dagan 50250, \\ Israel and ${ }^{2}$ Department of Veterinary Gynecology and Obstetrics, DGCN College of Veterinary and Animal Sciences, \\ Himachal Pradesh Agricultural University, Palampur, Himachal Pradesh 176 062, India
}

Correspondence should be addressed to U Moallem; Email: uzim@volcani.agri.gov.il

\begin{abstract}
Repeat breeder (RB) cows were compared with normal (CTRL) ones with respect to behavioral estrus intensity, endocrine patterns and concentrations of plasma estradiol, progesterone and LH around estrus, and ovulation timing. A total of 27 and 31 cycles in 12 RB and 18 CTRL cows, respectively, were synchronized by means of the Ovsynch protocol followed by a single PG injection after 7 days. Behavioral estrus and ovulation were observed in $\mathbf{8 1 . 5}$ and $\mathbf{8 3 . 8} \%$ of the synchronized cycles in the RB and CTRL cows respectively. The RB and CTRL groups had similar estrus durations of 21.4 and $19.6 \mathrm{~h}$ respectively, but estrus was more intense in the RB, as indicated by numerically higher overall activity indexes and higher peak neck activity. The interval from PG injection to estrus onset (considered as proestrus) was $8.2 \mathrm{~h}$ shorter in RB than in CTRL cows, at 47.9 and $56.1 \mathrm{~h}$ respectively $(P<0.007)$, but the average preovulatory follicle size was similar. The estradiol concentration at peak was numerically higher $(21 \%)$ and the AUC tended to be higher in the RB cows than in the CTRL cows. LH secretion during the period from 18 to $3 \mathrm{~h}$ before the LH peak was also lower in RB than in CTRL cows: 2.5 and $4.6 \mathrm{ng} / \mathrm{ml}$ respectively $(P<0.01)$. In conclusion, the behavioral estrus was more intense in the RB cows; nevertheless, short proestrus and subdued LH concentrations before the LH peak, which could impair oocyte competence and development, were first reported in RB cows.
\end{abstract}

Reproduction (2015) 149 545-554

\section{Introduction}

Irrespective of the management system, repeat breeding in dairy cows remains a major cause of infertility; it leads to major economic losses because of reproductive wastage, culling, replacement costs, and loss of genetic gain (Bartlett et al. 1986). On an individual cow basis, an optimal strategy for treatment of repeat breeding often remains elusive because of its multifactorial etiology, which involves cows, semen quality, and inseminator or insemination technique (see review by Walsh et al. (2011)). In females, several interrelated factors such as estrous behavior and certain endocrine aspects have been investigated in modern high-yielding repeat breeder (RB) cows. Prolonged and/or silent estrus has been observed in up to $50 \%$ of RB cows (Perez-Marin \& Espana 2007, Cummins et al. 2012). Several other extensive studies have indicated endocrine impairment in estrogen $\left(E_{2}\right)$, progesterone $\left(P_{4}\right)$, or luteinizing hormone (LH) as potential reasons for the repeat breeding phenomenon (Båge et al. 2002, Saumande \& Humbolt 2005, Bloch et al. 2006) - prolonged estrus and extended estrus-to-ovulation interval were common to all these studies. Clinically, prolonged estrus can be easily diagnosed and has been treated successfully (López-Gatius et al. 2001). However, RB cows with normal estrus duration and ovulation timings, which account for up to $37.8 \%$ of repeat breeding (Perez-Marin \& Espana 2007), remain a serious challenge because of the elusive etiology. Thus, the objectives of this study were to investigate the quantitative and sequential differences in estrous activity, hormonal patterns around estrus, and ovulation time as reason(s) for infertility in RB cows.

\section{Materials and methods}

The procedures used in this study were approved by the Volcani Center Animal Care Committee. Israeli Holstein lactating cows ( $>60$ days in milk) at the Volcani Center Experimental Farm (Bet Dagan, Israel) were used in this study, conducted during the winter (from mid-December 2013 to mid-March 2014), to avoid effects of heat stress. All the selected cows were normal cyclic, had normal estrus duration, and had no history of dystocia, retained placenta, or metritis, before the start of the study. The cows were grouped into two categories: control (CTRL) and RBs. The CTRL cows were $>60$ days in lactation, cycling, and not inseminated. A cow was considered as RB if it exhibited no clinically detected abnormality and did 
not become pregnant after at least four successive inseminations during spontaneous estrus, with normal intervals between artificial inseminations (Als). The average number of Als in the RB cows was $7.0 \pm 2.0$ (range: $4-11$ ). The reproductive health of the genital tracts of all the participating cows was reaffirmed by two successive examinations separated by a 10- to 11-day interval, by means of transrectal ultrasound examination with an Aquila $5-\mathrm{MHz}$ linear array transducer (Pie Medical, Maastricht, The Netherlands).

In total, $18 \mathrm{CTRL}$ and $12 \mathrm{RB}$ cows were used in the study, and the experiment was designed in three clusters, each comprising both CTRL and RB cows. A few cows were included in more than one cluster. The cows were fed according to NRC (2001) recommendations and were housed in the same covered loose pen with an adjacent outside yard. The animals were milked three times a day, and milk yields and body weights were automatically recorded daily with the AfiFarm System (SAE, Afikim, Israel). At the initiation of the synchronization protocol, body condition score (BCS) was determined in all animals by the same technician, according to Edmondson et al. (1989). One-week averages of body weight, milk, and fat-corrected milk (FCM 4\%) before the investigated estrus were considered as baseline data.

\section{Estrus synchronization, detection of ovulation, and bleeding schedule}

A schedule for synchronization and blood collection is presented schematically in Fig. 1. Following selection, the cows were synchronized using the Ovsynch protocol, followed by PG treatment 7 days later (Fig. 1). The GNRH1 and GNRH2 injected on days 0 and 9, respectively, comprised $200 \mu \mathrm{g}$ of gonadorelin acetate (Gonabreed; Parnell Living Science, Alexandria, NSW, Australia). The PG injected on day 7 (PG1) and day 16 (PG2) comprised $500 \mu \mathrm{g}$ of cloprostenol sodium (Estroplan; Parnell Living Science). After the PG2 injection, the cows were under intensive observations for the following 6 days; two persons visually monitored the cows round the clock for mounting activity or other behavioral signs typical of estrus (van Eerdenburg 2008). Starting at $15 \mathrm{~h}$ from estrus onset, the animals were monitored for ovulation time by repeated 6 h-interval examinations by transrectal ultrasonography, and ovulation was considered to occur $3 \mathrm{~h}$ before the last examination, when the preovulatory follicle disappeared from the ovary. The diameter of the preovulatory follicle was also recorded at the time of the first ultrasound screening for ovulation, i.e., $15 \mathrm{~h}$ after onset of estrus.

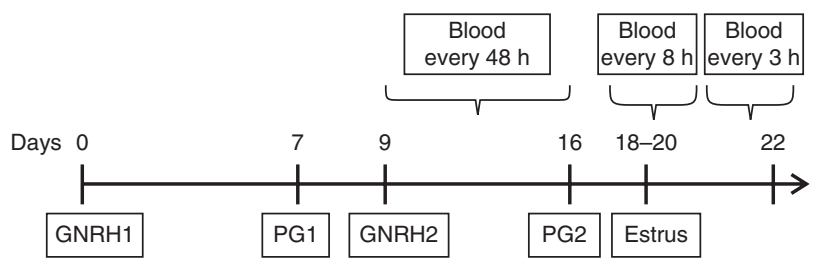

Figure 1 Schematic representation of estrus synchronization, estrus detection, and bleeding schedule.
From the GNRH2 injection on day 9 until the PG2 injection on day 16 , one blood sample was collected every $48 \mathrm{~h}$, and from PG2 injection onward every $8 \mathrm{~h}$ till estrus onset. From estrus onset, blood samples were collected every $3 \mathrm{~h}$ for $24 \mathrm{~h}$, i.e., a total of nine samples. The blood samples were collected from the jugular vein into vacuum tubes containing lithium heparin (Becton Dickinson System, Cowley, UK), and plasma was immediately separated by centrifugation for $15 \mathrm{~min}$ at $1000 \mathrm{~g}$ and was stored at $-32{ }^{\circ} \mathrm{C}$ pending analysis.

\section{Quantification of estrous activity}

Estrous activity was quantified according to neck movements and pedometer readings. However, because neck movements were recorded every $2 \mathrm{~h}$ and pedometer readings approximately every $8 \mathrm{~h}$, the former were used for detailed analysis. The cows were fitted with collar-mounted tags (H-tag; SCR Engineers, Hadarim, Netanya, Israel) equipped with a threedimensional accelerometer. Neck movements were analyzed and filtered by means of complex algorithms in an on-board central processing unit (CPU). The result was a dimensionless 'activity index' that was stored in 12 2-h memory cells inside the $\mathrm{H}$-tag and was recorded three times daily at the milking parlor. Moreover, for estrus quantification by locomotion assessment, the cows were fitted with a pedometer system (AfiFarm System; SAE). Pedometer readings were taken thrice daily at 8-h intervals at the milking parlor, and analyzed automatically by the herd management computer program.

The neck activity index, recorded at 2-h intervals, was considered in terms of actual values, and also by calculating percentage deviations of the actual values from the average of the base values that were recorded on the same clock timings during the 7 days preceding estrus. Estrus onset and duration, as detected visually, coincided with the increase in percentage deviation; therefore, the first increase in activity by $\geq 50 \%$ and the last observation indicating decreased activity to $\leq 50 \%$ of the base values were considered as the beginning and end of estrus respectively. The percentage deviation data were used for calculating area under the curve (AUC) for plots vs time of mean estrous activity for all 2-h intervals during estrus, which signified estrus intensity, peak activity, time from estrus onset to peak activity, and estrus duration. The pedometer activity index was calculated in a way similar to neck activity, except that a $75 \%$ difference from base activities was taken to indicate estrus.

\section{Schedule, methods, and components of endocrine events in blood plasma}

Estradiol 17B $\left(\mathrm{E}_{2}\right)$ was determined in the first three samples collected every $8 \mathrm{~h}$ preceding estrus, and in the first five samples after estrus onset. The $E_{2}$ concentration was determined with RIA (DSL4800; Beckman Coulter, Inc., Brea, CA, USA) after extraction of $1 \mathrm{ml}$ of plasma by elution with methanol (Shore et al. 1998), on C-18 solid-phase columns (Bond Elut-C18, $500 \mathrm{mg} 3 \mathrm{ml}$; Varian, Lake Forest, CA, USA). The antibody for $E_{2}$ bonded $100 \%$ to $E_{2}$ and $50 \%$ to estrone. Sensitivity of the $E_{2}$ assay was $2 \mathrm{pg} / \mathrm{ml}$. Progesterone was determined in the nine samples collected from the time of PG1 
until $48 \mathrm{~h}$ after PG2, and in three samples taken at estrus onset $(0 \mathrm{~h})$, and 12 and $24 \mathrm{~h}$ after estrus onset. The $\mathrm{P}_{4}$ concentration was determined by RIA (Diagnostic Products, Los Angeles, CA, USA), with a $\mathrm{P}_{4}$ detection threshold of $0.2 \mathrm{pg} / \mathrm{ml}$. The $\mathrm{LH}$ was determined in all nine samples collected after estrus onset; $\mathrm{LH}$ concentrations were measured using the LH EIA kit (INRA, Nouzilly, France), with a detection threshold of $0.6 \mathrm{ng} / \mathrm{ml}$. The inter- and intra-assay coefficient of variation values, respectively, were 4.1 and $3.6 \%$ for $E_{2}$, and 9.2 and $8.5 \%$ for $P_{4}$.

The $E_{2}$ and $\mathrm{LH}$ were analyzed for peak concentrations and also after normalizing the data to the respective peaks, and for the time of peak in relation to PG2 injection and to estrus onset. Values of $\mathrm{E}_{2}$ and $\mathrm{LH}$ plasma concentrations were also transformed to AUC against time (hours) by the trapezoid method (Altman 1991).

\section{Statistical analysis}

The $E_{2}$ and $\mathrm{LH}$ concentrations and AUC in plasma, estrous activity, and timing were analyzed as repeated measurements by the MIXED procedure, version 9.2 (SAS 2002). The effects of treatment, cow, and cluster were included in the model. The autoregressive order 1 (AR 1) was used as a covariance structure in the model.

Distributions of cows with differing intervals from PG administration to $E_{2}$ and $\mathrm{LH}$ estrus peaks were analyzed by the $\chi^{2}$ procedure of SAS (2002).

Least-squares means and adjusted S.E.M.s are presented in tables; the significance level was $P<0.05$ unless otherwise stated.

\section{Results}

The general information on the cows included in the study was as follows. The average values (mean \pm s.D.) in the CTRL and the RB group, respectively, were: milk, $44.3 \pm 9.8$ and $34.6 \pm 6.5 \mathrm{~kg} /$ day; FCM (4\%), $41.3 \pm 7.5$ and $33.4 \pm 6.0 \mathrm{~kg} /$ day; parity, $2.4 \pm 1.6$ and $2.1 \pm 1.3$; body weight, $637.2 \pm 80.1$ and $682.4 \pm 66.1 \mathrm{~kg}$; day in milk (DIM), $107.5 \pm 33.6$ and $349.7 \pm 59.7$ days; and BCS, $2.8 \pm 0.2$ and $2.9 \pm 0.1$. Twenty-six out of 31 (83.8\%) CTRL cows and 22 out of 27 (81.5\%) RB cows responded to the estrus synchronization, exhibited behavioral estrus, and ovulated.

The average activity index, evaluated as actual points of neck activity during estrus, did not differ between the two groups in any of the 2-h intervals. However, when considered in terms of percentage deviation from the base values, the average neck activity was higher in the RB cows in most of the 2 -h intervals (Table 1 and Fig. 2A). Consequently, the AUC for the percentage increases and the average deviation for all the 2-hinterval records tended to be higher in the RB cows than in the CTRL cows $(P<0.1$; Table 1$)$. The peak activity was also $30 \%$ higher in the RB cows than in the CTRL cows $(P<0.04)$. However, the interval from estrus onset to peak activity was $1.6 \mathrm{~h}$ shorter in the CTRL cows than in the RB cows $(P<0.1)$. Estrus duration did not differ
Table 1 Comparison between average (mean \pm s.E.M.) estrous activity parameters of control (CTRL) and repeat breeder (RB) cows.

\begin{tabular}{|c|c|c|c|c|}
\hline \multirow[b]{2}{*}{ Parameter } & \multicolumn{2}{|c|}{ Group } & \multirow[b]{2}{*}{ S.E.M. } & \multirow[b]{2}{*}{$\boldsymbol{P}<$} \\
\hline & CTRL & RB & & \\
\hline \multicolumn{5}{|l|}{ Neck activity ${ }^{\mathrm{a}}$} \\
\hline Intensity ${ }^{\mathrm{b}}$ & 159.5 & 186.8 & 9.9 & 0.11 \\
\hline AUC & 1520.8 & 1914.1 & 117.0 & 0.10 \\
\hline Peak activity & 331.3 & 428.1 & 29.3 & 0.04 \\
\hline Estrus onset to peak (h) & 11.3 & 12.9 & 0.73 & 0.13 \\
\hline Estrus duration (h) & 19.6 & 21.4 & 1.05 & 0.25 \\
\hline \multicolumn{5}{|l|}{ Pedometer ${ }^{\mathrm{c}}$} \\
\hline Intensity ${ }^{\mathrm{d}}$ & 283.3 & 319.8 & 19.2 & 0.24 \\
\hline
\end{tabular}

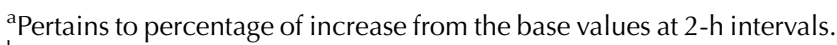
${ }^{\mathrm{b}}$ Combined activity for all $2-\mathrm{h}$ intervals. ${ }^{\mathrm{C}}$ Pertains to percentage of increase from the base values at 8 -h intervals. ${ }^{\mathrm{d}}$ Combined activity for all 8-h intervals.

between the two groups. Better estrus expression in the RB cows was also confirmed by numerically higher pedometer activity during estrus (Table 1).

The average plasma $E_{2}$ concentrations for most of the surge timings were numerically higher in RB cows than in CTRL cows (Fig. 2B), which led to a tendency for a higher $A \cup C$ of $E_{2}$ in the RB cows than in the CTRL cows (Table $2 ; 105.2$ vs $85.6 \mathrm{pg} / \mathrm{ml} \times$ h respectively; $P<0.13$ ). The average peak plasma LH concentration did not differ between the groups. However, before the ascending limb of the $\mathrm{LH}$ peak $(-18$ to $-3 \mathrm{~h})$, the pooled $\mathrm{LH}$ concentrations were lower $(P<0.01)$ in RB cows than in CTRL cows, at $2.5 \pm 0.1$ and $4.6 \pm 0.6 \mathrm{ng} / \mathrm{ml}$ respectively (Fig. 2C). The intervals from $\mathrm{E}_{2}$ peak to $\mathrm{LH}$ peak did not differ between the two groups of cows (Table 2).

Average plasma $\mathrm{P}_{4}$ concentrations at various points during the synchronization procedure and estrus are presented in Fig. 3. Except for the time of PG1, which was sampled blindly, the plasma $\mathrm{P}_{4}$ concentrations were similar between the two groups during the synchronization protocol and estrus.

The intervals from PG2 injection to ovulation, endocrine-related events, and estrus onset are given in Table 2. Unlike the RB cows, all of which were in estrus within $60 \mathrm{~h}$ after PG2 injection, $\sim 31 \%$ of the CTRL cows started behavioral estrus after more than $60 \mathrm{~h}(P<0.004$; Fig. 4A). Furthermore, almost all the RB cows exhibited $\mathrm{E}_{2}$ (Fig. 4B) and $\mathrm{LH}$ (Fig. 4C) peaks within $70 \mathrm{~h}$ after PG2 injection $\left(P<0.009\right.$ and $P<0.02$, for $\mathrm{E}_{2}$ and $\mathrm{LH}$ respectively), whereas approximately one-third of the CTRL cows took more than $70 \mathrm{~h}$ to reach the respective endocrine peaks (Fig. 4B and $\mathrm{C}$ respectively). The onset of estrus relative to the $\mathrm{PG} 2$ injection was on average $8.2 \mathrm{~h}$ earlier in the RB cows than in the CTRL cows $(P<0.007$; Table 2 and Fig. 5A). Furthermore, times from PG2 administration to $\mathrm{E}_{2}(P<0.08$; Fig. $5 \mathrm{~B})$ and $\mathrm{LH}(P<0.009$; Fig. 5C) peaks were $\sim 8 \mathrm{~h}$ earlier in the RB cows.

The time from estrus onset to ovulation did not differ between the two groups. The average pre-ovulatory follicular diameter, recorded $15 \mathrm{~h}$ after estrus onset, was 

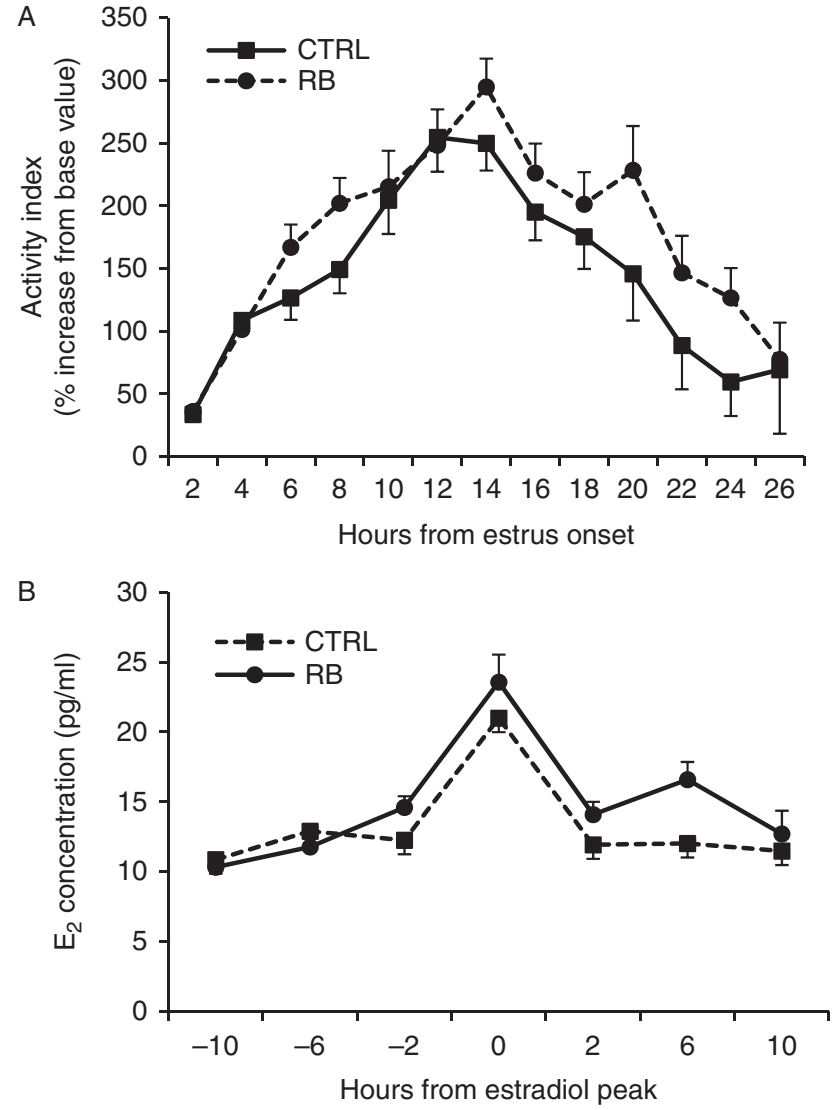

C

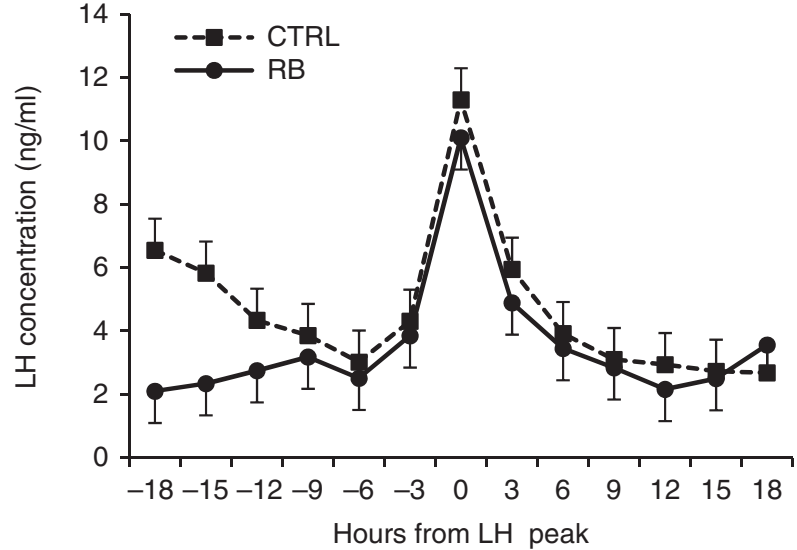

Figure 2 Average (mean \pm s.E.M.) percentage increase from base values of neck activity (A) at 2-h intervals during estrus in CTRL (filled square) and RB (filled circle) cows; average $E_{2}$ concentartion in blood relative to $E_{2}$ peak (B) in CTRL (filled square) and RB (filled circle) cows; average $\mathrm{LH}$ concentartion in blood relative to LH peak (C) in CTRL (filled square) and RB (filled circle) cows.

also similar between the CTRL $(17.7 \pm 0.5 \mathrm{~mm})$ and the RB $(17.0 \pm 0.6 \mathrm{~mm})$ cows.

\section{Discussion}

A prerequisite for optimal timing of $\mathrm{Al}$ and oocyte fertilization is the cow's ability to exhibit behavioral estrus and manifest a successful ovulation. In this study, we investigated the quantitative and sequential events with respect to behavioral estrus intensity and endocrine patterns around estrus of RB cows compared with normal cows. The behavioral estrus was more intense in the RB cows and ovulation timing was within the normal range in both groups. However, short proestrus and subdued LH secretory pattern before the LH peak, which could impair oocyte competence and development, could be the potential reasons for reproductive failure in RB cows.

\section{Estrus intensity and ovulation time}

In general, the average duration and range of the estrous period recorded in the RB and CTRL cows in this study were within the normal range and similar to the 20.3-h duration recorded previously (Lyimo et al. 2000). Reductions in both intensity and duration of estrus form a major contributing factor to the decline in reproduction efficiency in modern dairy cows (Law et al. 2009). Stevenson et al. (1983) found a positive correlation between estrus intensity and fertility in cattle, and Cummins et al. (2012) found that, in Holstein cows grouped according to the high and low fertility history, the peak estrous activity was $41 \%$ higher in those with a high fertility history. Previous investigations of estrus expression and ovarian function in RB cows or those with low fertility history revealed that $\sim 22 \%$ of them exhibited silent heat (Perez-Marin \& Espana 2007, Cummins et al. 2012). However, these findings contradict those of this study, in which more intense estrus and higher peak activity were observed in RB cows than in CTRL cows. The discrepancy between these findings could be explained as follows: within a certain group of cows, differences in estrus intensity could be related to fertility performance; however, in this study, by design, we compared two distinct groups that comprised $\mathrm{RB}$ and normal cows respectively. No other studies

Table 2 Comparison between control (CTRL) and repeat breeder (RB) cows with regard to average (mean \pm s.E.M.) estrus- and endocrinerelated characteristics, as related to $\mathrm{PG}$ and estrus onset.

\begin{tabular}{|c|c|c|c|c|}
\hline \multirow[b]{2}{*}{ Parameter } & \multicolumn{2}{|c|}{ Group } & \multirow[b]{2}{*}{ S.E.M. } & \multirow[b]{2}{*}{$\boldsymbol{P}<$} \\
\hline & CTRL & RB & & \\
\hline PG to estrus onset (h) & 56.1 & 47.9 & 1.95 & 0.007 \\
\hline PG to $E_{2}$ peak (h) & 58.0 & 50.2 & 3.04 & 0.08 \\
\hline PG to LH peak (h) & 65.2 & 57.5 & 1.91 & 0.009 \\
\hline PG to ovulation (h) & 84.1 & 79.6 & 2.4 & 0.20 \\
\hline Estrus onset to $E_{2}$ peak (h) & 2.1 & 2.5 & 1.93 & 0.97 \\
\hline Estrus onset to LH peak (h) & 9.3 & 9.5 & 1.3 & 0.90 \\
\hline $\mathrm{E}_{2}$ peak to $\mathrm{LH}$ peak $(\mathrm{h})$ & 7.2 & 7.2 & 1.96 & 0.98 \\
\hline LH peak to ovulation (h) & 20.2 & 21.7 & 1.5 & 0.48 \\
\hline Estrus onset to ovulation (h) & 28.9 & 31.5 & 1.58 & 0.25 \\
\hline $\mathrm{E}_{2}$ concentration at peak $(\mathrm{pg} / \mathrm{ml})$ & 18.8 & 22.7 & 2.13 & 0.21 \\
\hline $\mathrm{AUC}-\mathrm{E}_{2}(\mathrm{pg} / \mathrm{ml} \times \mathrm{h})$ & 85.6 & 105.2 & 7.48 & 0.13 \\
\hline LH concentration at peak (ng/ml) & 10.5 & 10.1 & 0.58 & 0.63 \\
\hline $\mathrm{A} \cup \mathrm{C}-\mathrm{LH}(\mathrm{ng} / \mathrm{ml} \times \mathrm{h})$ & 34.2 & 32.4 & 1.76 & 0.48 \\
\hline
\end{tabular}

www.reproduction-online.org 


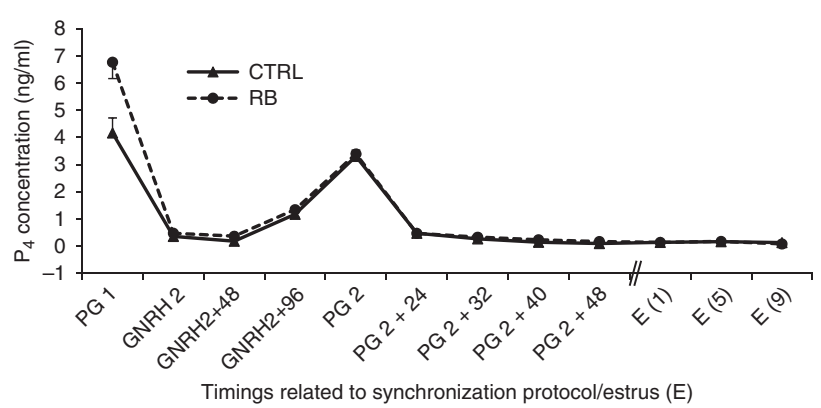

Figure 3 Average (mean \pm S.E.M.) plasma progesterone concentration at various stages of synchronization and estrus in CTRL (filled square) and RB (filled circle) cows (// separates pre-estrous from estrous periods). $E(1), E(5)$, and $E(9)$ are the first, fifth, and ninth samples collected at estrus onset, and 12 and $24 \mathrm{~h}$ after estrus onset respectively.

have quantified estrus intensity in RB cows with normal estrus duration.

Several other studies attributed the failure of fertility in RB cows or those with low fertility history to delayed ovulation (Båge et al. 2002, Saumande \& Humbolt 2005, Bloch et al. 2006) or ovulation failure (López-Gatius et al. 2005a, Demetrio et al. 2007, Cummins et al. 2012). However, in this study, in spite of slightly longer estrus-toovulation interval in the RB cows than in the CTRL cows (31.5 vs $28.9 \mathrm{~h} ; \mathrm{NS}$ ), all the CTRL and RB respondent cows ovulated within the normal range. Thus, in this study, estrus intensity and ovulation perturbations were, at least, not the underlying causative factors of infertility in the RB cows.

\section{Hormones and behavioral estrus intensity}

In several studies, the intensity and duration of estrus were positively related to circulating $\mathrm{E}_{2}$ concentration (Katz et al. 1980, Britt et al. 1986, Lyimo et al. 2000, Lopez et al. 2004). However, examination of ovariectomized progesterone-primed cows revealed that those cows maintained on higher circulating $E_{2}$ (12 vs $6 \mathrm{pg} / \mathrm{ml}$ ) exhibited increased estrus duration (17.1 vs $8.8 \mathrm{~h}$ ), but similar estrus intensities (Reames et al. 2011). In contrast, in this study, the RB cows that had higher circulating $\mathrm{E}_{2}$ exhibited higher estrus intensity, but similar estrus duration to the CTRL cows. Some other reports, however, suggested a threshold level rather than circulating concentrations of $\mathrm{E}_{2}$ to trigger 'complete' estrus, and that the increasing $E_{2}$ concentration increased neither the duration nor the intensity of estrus (Glencross et al. 1981, Cook et al. 1986, Coe \& Allrich 1989, Allrich 1994). Furthermore, variation in estrus characteristics at an individual or herd level cannot be precluded (Bertilsson et al. 1998).

A negative correlation between estrus intensity and $\mathrm{P}_{4}$ concentration around ovulation might be another factor that influences estrus intensity (Waldmann et al. 2001). Davidge et al. (1987) found that heat signs were depressed in a dose-dependent manner after $\mathrm{P}_{4}$ supplementation, and suggested that $\mathrm{P}_{4}$ blocked the estrus-inducing action of $E_{2}$. However, no differences in $\mathrm{P}_{4}$ concentrations between groups were observed in this study (Fig. 3); therefore, we hypothesize that higher estrus intensity in the RB cows was linked directly to higher $E_{2}$ concentrations. Moreover, a lack of $P_{4}$ differences between the groups during the estrus in this study also rules out the suprabasal $\mathrm{P}_{4}$-related behavioral, ovarian, and endocrine disturbances such as prolonged estrus, weak estrus expression, a prolonged interval between estrus onset and LH peak, or delayed ovulation, that had been blamed for repeat breeding in cattle (Duchens et al. 1994, Båge 2003, Singh et al. 2005).
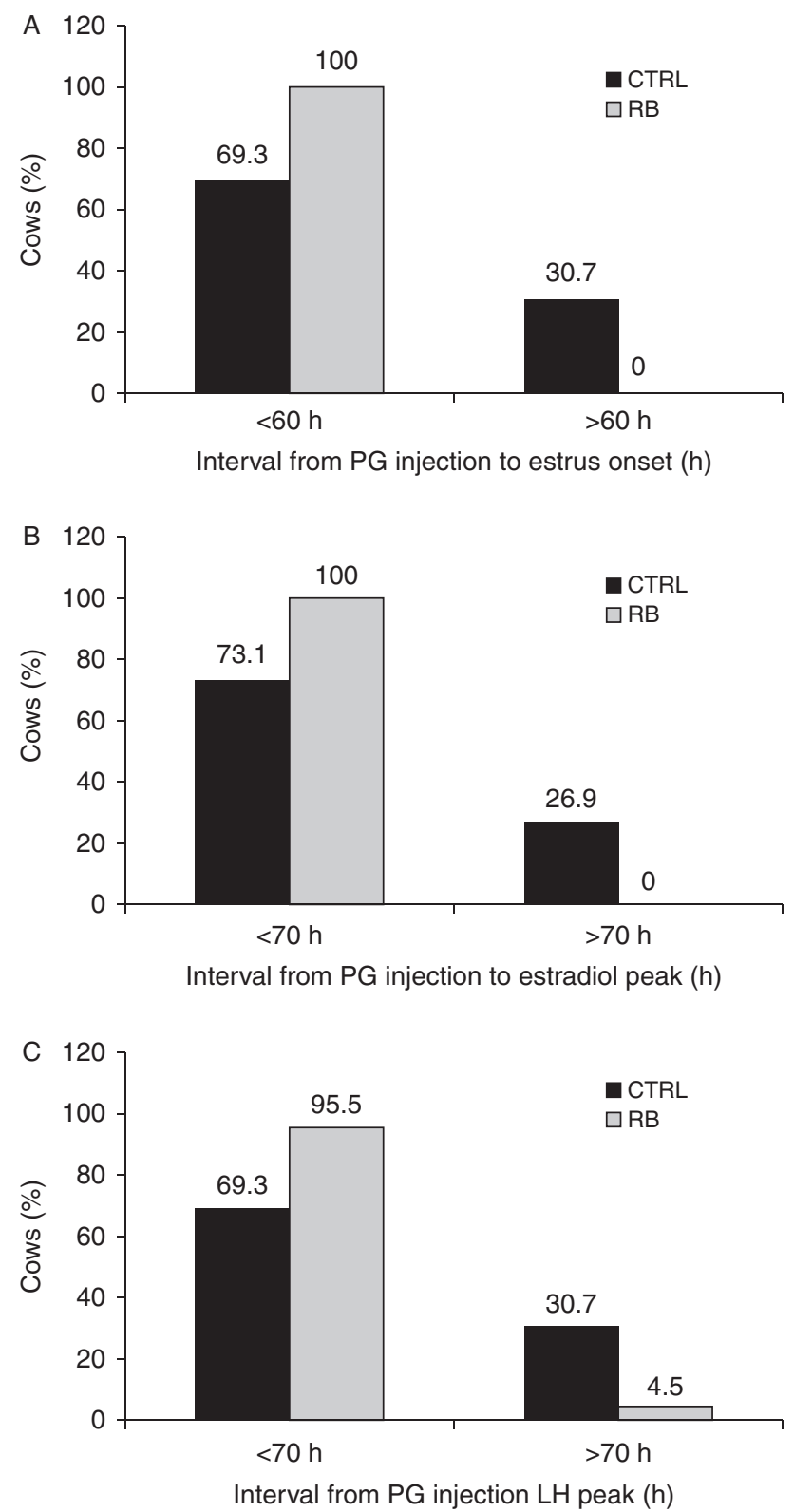

Figure 4 Distribution (\%) of cows among time intervals from PG administration to estrus onset (A), estradiol peak (B), and LH peak (C) after PG administration in CTRL (filled square) and RB (filled circle) cows. 

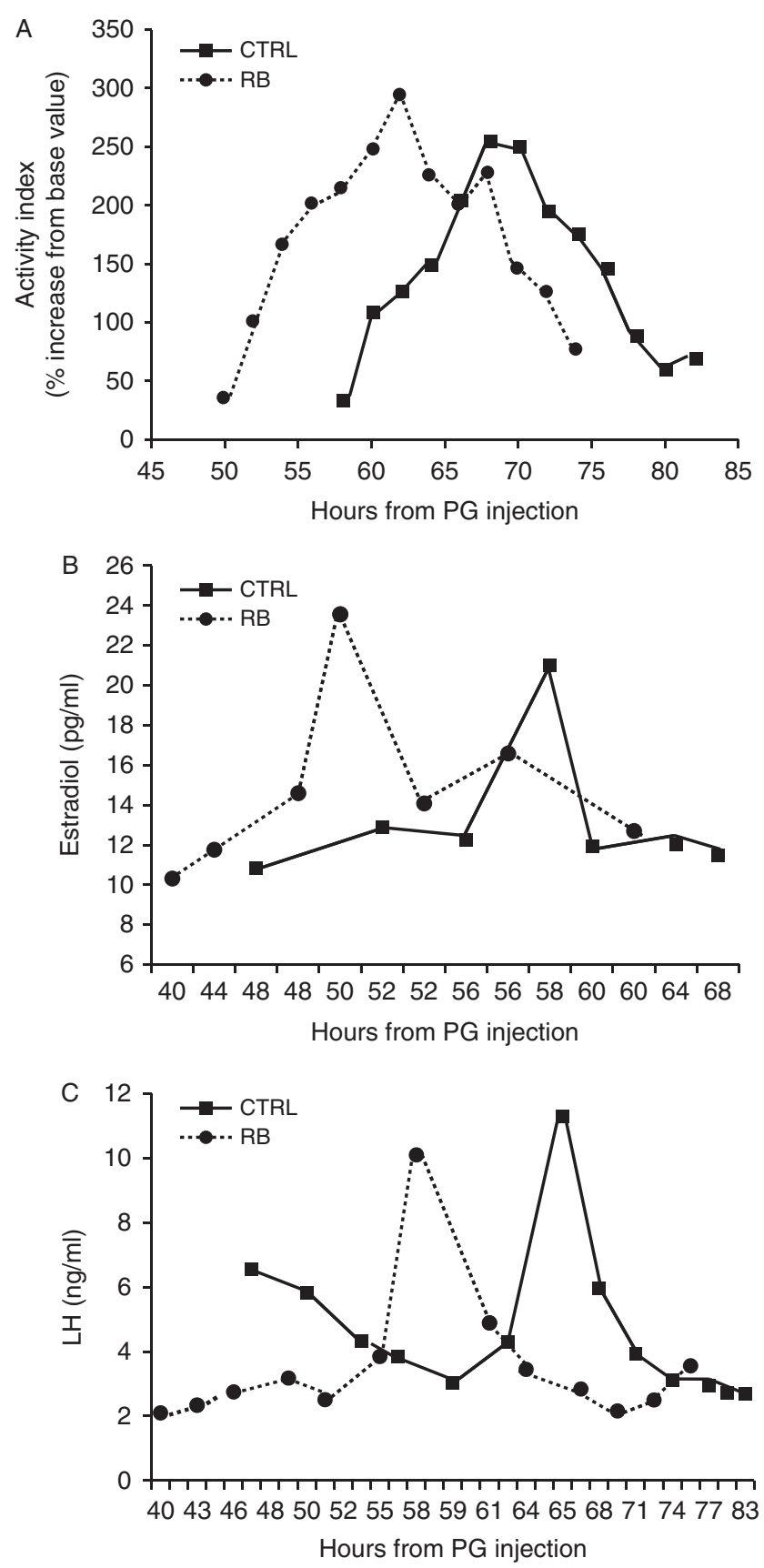

Figure 5 Average percentage increase from base values of neck activity (i.e., estrus onset (A)), $\mathrm{E}_{2}(\mathrm{~B})$, and $\mathrm{LH}(\mathrm{C})$ blood concentrations relative to the time of PG2 injection in CTRL (filled square) and RB (filled circle) cows.

\section{Timing of estrus onset, $E_{2}$, and $L H$ peaks}

In this study, the interval between PG2 injection and estrus onset, $\mathrm{E}_{2}$, and $\mathrm{LH}$ peaks was $\sim 8 \mathrm{~h}$ shorter in the $\mathrm{RB}$ cows than in the CTRL cows (Fig. 5A, B and C respectively) and, furthermore, all the RB cows entered estrus within $60 \mathrm{~h}$ after PG2 administration compared with only $69.3 \%$ of the CTRL cows (Fig. 4A). A variation in the interval from PG administration to the onset of estrus has previously been analyzed from three different viewpoints: i) the stage of estrous cycle at the time of PG injection; ii) variations in $\mathrm{P}_{4}$ concentration; and iii) differences in the size and maturity of the dominant follicle. In the earlier studies, the stage of estrous cycle at the time of PG injection was considered in itself as the reason for variation. When PG was given between days 5 and 8 of the estrous cycle, the mean time to estrus ranged from 48 to 72 h (Tanabe \& Hann 1984, Watts \& Fuquay 1985); this was, however, extended to $70 \mathrm{~h}$ when PG was injected between days 8 and 11 of the cycle (King et al. 1982, Stevenson et al. 1984). If the day of GNRH2 injection was considered as day 0 in this study and PG2 administered 7 days later, the time taken for estrus onset was similar to that found in the studies cited earlier but, characteristically, all the RB cows responded within the lower levels of the timing range. Variations of $\mathrm{P}_{4}$ concentration could be another factor regulating estrus onset (Larson \& Ball 1992). However, in this study, similar $\mathrm{P}_{4}$ concentrations at the time of PG2 administration were found in both groups (Fig. 3), which excluded $\mathrm{P}_{4}$ variation as a reason for early estrus onset in the RB group. The third reason could be differences in the size and maturity of the most recently emerged dominant follicle at the time of PG administration (Kastelic \& Ginther 1991, Twagiramungu et al. 1992, 1995, Ferguson \& Galligan 1993). The GNRH2 in the Ovsynch protocol ovulates $86-100 \%$ of the preovulatory follicles generated from GNRH1 in cyclic cattle (Wiltbank 1998). In such a case, it can be assumed that most, if not all, of the cows in the present experiment were in a similar follicular status following GNRH2, and this assumption is also supported by a similarity in $\mathrm{P}_{4}$ concentrations and the diameters of pre-ovulatory follicles recorded $15 \mathrm{~h}$ after estrus onset. The similar diameters of preovulatory follicles also indicate that the rate of follicular development could have been faster in the RB cows; the average sizes mentioned earlier in this study were reached within 62.9 and $71.1 \mathrm{~h}$ after PG2 administration in RB and CTRL cows respectively. Thus, the only plausible explanation for earlier estrus onset in the RB cows when compared with the CTRL cows must be the higher $E_{2}$ concentration at the time of estrus onset.

The peak $E_{2}$ and $\mathrm{LH}$ concentrations in this study were within the range of those reported previously (Ribadu \& Nakao 1999, Saumande \& Humbolt 2005). The sequence and time relationships among the various endocrine/ovulation events in this study were also consistent with most of the related data published thus far (Schams et al. 1977, Dieleman et al. 1986, Larsson 1987, Rajamahendran et al. 1989, Stevenson et al. 1998, Saumande \& Humbolt 2005), but there were some exceptions. In seven CTRL and five RB cows, the $E_{2}$ peak preceded estrus onset and, in four CTRL and four RB cows, the $\mathrm{LH}$ peak preceded the $\mathrm{E}_{2}$ peak. In the latter 
group, both peaks occurred after estrus onset; occurrence of the $\mathrm{LH}$ peak before estrus reduces fertility (Saumande \& Humbolt 2005, Bloch et al. 2006). The exceptions described earlier in this study are not uncommon and were recorded in previous studies (Cook et al. 1986, Coe \& Allrich 1989, Reames et al. 2011).

\section{Proestrous period}

Early estrus onset in the RB cows could have two implications. First, the short fertile half-life of gametes restricts the period of breeding and fertilization (Nebel et al. 2000); therefore, adopting a fixed time for Al could not yield similar conception rates in the two groups of cows, as arranged in this study. Hence, estrus detection should be included in the Al protocol of programed breeding, or the timing of blind Al should be adjusted in light of the new findings. The second implication is the duration of proestrous period, which begins with the luteolytic pulses of PG and CL lysis. Early return to estrus, as demonstrated in the RB cows in this study, can be considered as a short proestrous period. There are several compelling findings that associate lower conception rates in cows with reduced proestrus duration: Dadarwal et al. (2013) found that cows with proestrus of 12 and $36 \mathrm{~h}$ had conception rates of 11 and $46 \%$ respectively. Ribeiro et al. (2012) found a similar trend of lower conceptions rates in cows with shorter proestrous period. Although not consistent among various studies, smaller follicles and low $E_{2}$ contents in cows with short proestrus have, in themselves, been the probable reasons for reproduction failure. Mussard et al. (2003a) reported that a proestrus of $52.8 \pm 2.4 \mathrm{~h}$ and the corresponding follicular diameter of $13.6 \pm 0.2 \mathrm{~mm}$ resulted in a conception rate of $57 \%$; and Mussard et al. (2003b) found that a proestrus of $24.0 \pm 2.4 \mathrm{~h}$ with the corresponding follicular diameter of $11.1 \pm 0.2 \mathrm{~mm}$ resulted in a conception rate of $8 \%$. The same group reaffirmed the importance of proestrus length for conception rates, irrespective of follicular diameter (Mussard et al. 2007), which was also found by Bridges et al. (2010).

It is known that priming of the reproductive tract with ovarian steroids for an optimal period benefits reproduction, for example, after synchronization with a double PG system, injected 13 days apart, fertility increased by $\sim 10 \%$ in the cows supplemented with $\mathrm{P}_{4}$ for 5 days before the second PG administration (Xu et al. 1996). Accordingly, we hypothesize that short proestruslinked $E_{2}$ exposure of the reproductive tract limits its direct roles in production of the oviductal secretory glycoproteins (Buhi 2002) and in uterine receptivity (Ozturk \& Demir 2010) required to increase the success of fertilization and improve embryo quality and viability (Atkins et al. 2013, Jinks et al. 2013). Furthermore, the frequency of abnormal embryos was enhanced in the oviducts of RB cows (Linares et al. 1980). Whether the latter observation is linked to altered $E_{2}$ exposuremediated production of oviductal secretory glycoproteins needs further investigation; evaluation of oocyte competence can provide some clues regarding the etiology of repeat breeding.

\section{LH curve}

Higher $E_{2}$ stimulated higher LH (Short et al. 1979). However, in the RB cows, in this study, in spite of increased $E_{2}$ we recorded low $\mathrm{LH}$ before its peak (Fig. 2C). This again could be a consequence of a short proestrus. A short $E_{2}$ exposure influenced neither the timing of the $\mathrm{LH}$ surge onset nor the amplitude of the GNRH surge, but less LH was released, which suggests a requirement for longer $E_{2}$ priming at the pituitary gland, to enable the full amplitude of LH secretion (Evans et al. 1997). The LH surge, which lasts for $8-10 \mathrm{~h}$ in cows (Chenault et al. 1975), triggers oocyte maturation and, accordingly, the LH surge has been the focus of nearly all investigations. However, the changes within the oocyte begin much earlier, and low pre-surge $\mathrm{LH}$ concentrations may prevent the development of a normal oocyte. For instance, at $2 \mathrm{~h}$ pre-LH surge, the gene expression of the cumulus cells is set to receive the last major induction of final oocyte maturation. In cows, under normal LH secretory mechanisms, mainly two genes - tribbles homolog 2 (TRIB2) and ERBB receptor feedback inhibitor (ERRFI1) - had significantly higher expression in the cumulus cells around oocytes at $2 \mathrm{~h}$ before the LH surge than those evaluated $6 \mathrm{~h}$ after the LH surge. In cattle, a stronger expression of these genes along with a few others terminated the progression/proliferation of cumulus cells, so that they could undergo rapid extracellular matrix expansion after the LH surge (Assidi et al. 2010). Thus, a lower LH concentration before the LH peak may prevent normal changes in the cumulus cells in the RB cows. Furthermore, a low pre-surge $\mathrm{LH}$ concentration is also a reason for a slightly longer estrus-to-ovulation interval in the RB cows than in the CTRL ones (31.5 vs $28.9 \mathrm{~h}$ ), as observed previously (Bloch et al. 2006). It is worth mentioning that in all previous studies that related length of proestrus to fertility, the duration of proestrus was experimentally manipulated, and it was truncated by generating an $\mathrm{LH}$ surge using exogenous GNRH, in contrast to the spontaneous LH surge in this study. Moreover, the $\mathrm{LH}$ concentrations before the induced surge were beyond the scope of previous studies; therefore, the present findings are unique.

As the RB cows had been inseminated up to 11 times and had a much longer post partum period, there were conspicuous, but inevitable differences between the CTRL and the RB cows in DIM, BCS, and milk yields. These differences need to be discussed in light of the present findings. It has been observed that, after the first silent estrus post partum, the DIM and the number of previous estruses did not affect the estrus intensity 
(Yániz et al. 2006). Similarly, variation in BCS does not affect the duration of estrus in beef cows (Castro et al. 2013). In this study, the average milk yield in the CTRL cows was significantly higher than that in the RB cows: 44.3 and $34.6 \mathrm{~kg} /$ day respectively. The $E_{2}$ concentration was also higher in the RB animals, whereas the $\mathrm{P}_{4}$ concentrations in the two groups remained similar. There are conflicting findings on the effect of milk yield on estrus expression in cows. van Eerdenburg (2008) suggested no correlation between milk yield and estrus expression, while several other studies considered that increased metabolic clearance of ovarian steroids in high yielders reduced the behavioral manifestations of estrus (Lopez et al. 2004, López-Gatius et al. 2005b). Lopez et al. (2004) reported that cows with higher milk yield had a lower serum $E_{2}$ concentration on the day of estrus and greatly reduced estrus duration compared with those with lower yields. Similarly, in another study on estrus events, each 1-kg increase in milk yield was associated with a $1.6 \%$ decrease in walking activity (López-Gatius et al. 2005b). These results fit with the findings of this study, in which the CTRL had higher milk yields, and lower $E_{2}$ concentration and estrus intensity than the RB cows. Furthermore, increased $E_{2}$ in the RB cows might be due to more steroidogenically active follicle, as, in another experiment, we have found higher $\mathrm{E}_{2}$ concentrations in the follicular fluid from $\mathrm{E}_{2}$-active follicles in a group of RB cows than in normal cows ( $\mathrm{P}$ Sood, unpublished data).

A limitation to our study is the possibility of CTRL cows to fall into the RB category. However, as stated earlier in this study, we have taken a few means to exclude cows with any history (as dystocia, retained placenta, etc.) and monitored ovaries and uterus to minimize the likelihood of having potential RB in the CTRL group. Similar to that, we have defined the RB as cows that did not conceive after at least four Als, although there was a chance of these cows to conceive in the following Al. We were well aware of these limitations when planning the study, and also believe that this is inevitable in such a study.

In conclusion, the occurrence of better estrus expression, similar follicular diameters, and higher $E_{2}$ in RB cows when compared with CTRL cows indicates that the etiology of repeat breeding lies beyond these parameters. However, a short proestrus and subdued LH secretory pattern, especially before the $\mathrm{LH}$ peak, could be the potential reasons for reproductive failure in RBs. Subsequent validation of the curative measures per se would be of immense importance.

\section{Declaration of interest}

The authors declare that there is no conflict of interest that could be perceived as prejudicing the impartiality of the research reported.

\section{Funding}

This research was financially supported by the Israeli Dairy Board, Yehud, Israel (362-378-13).

\section{Acknowledgements}

The authors thank the staff of the experimental farm of the Volcani Center for assistance with cow management, and their great help with observations and blood sampling during the very intensive work of this study.

\section{References}

Allrich RD 1994 Endocrine and neural control of estrus in dairy cows. Journal of Dairy Science 77 2738-2744. (doi:10.3168/jds.S00220302(94)77216-7)

Altman DG 1991 Some common problems in medical research. Serial measurements. In Practical Statistics for Medical Research, pp 426-433. Ed GB Cornwall. London: Chapman \& Hall (TJ Press (Padstow) Ltd).

Assidi M, Dieleman SJ \& Sirard MA 2010 Cumulus cell gene expression following the LH surge in bovine preovulatory follicles: potential early markers of oocyte competence. Reproduction 140 835-852. (doi:10. 1530/REP-10-0248)

Atkins JA, Smith MF, MacNeil MD, Jinks EM, Abreu FM, Alexander LJ \& Geary TW 2013 Pregnancy establishment and maintenance in cattle. Journal of Animal Science 91 722-733. (doi:10.2527/jas.2012-5368)

Båge R 2003 Conception rates after Al in Swedish red and white dairy heifers: relationship with progesterone concentrations at AI. Reproduction in Domestic Animals 38 199-203. (doi:10.1046/j.1439-0531.2003. 00426.x)

Båge R, Gustafsson H, Larsson B, Forsberg M \& Rodríguez-Martínez H 2002 Repeat breeding in dairy heifers: follicular dynamics and estrous cycle characteristics in relation to sexual hormone patterns. Theriogenology 57 2257-2269.

Bartlett PC, Kirk HJ \& Mather EC 1986 Repeated insemination in Michigan Holstein-Friesian cattle: incidence, descriptive epidemiology and estimated economic impact. Theriogenology 26 309-322. (doi:10. 1016/0093-691X(86)90150-0)

Bertilsson J, Berglund B, Osterman S, Rehn H \& Tengroth G 1998 Extended calving intervals - a way to optimise future milk production? 1. Effects on productivity. 49th European Association for Animal Production Meeting, Warsaw, Poland.

Bloch A, Folman Y, Kaim M, Roth Z, Braw-Tal R \& Wolfenson D 2006 Endocrine alterations associated with extended time interval between estrus and ovulation in high-yield dairy cows. Journal of Dairy Science 89 4694-4702. (doi:10.3168/jds.S0022-0302(06)72520-6)

Bridges GA, Mussard ML, Burke CR \& Day ML 2010 Influence of the length of proestrus on fertility and endocrine function in female cattle. Animal Reproduction Science 117 208-215. (doi:10.1016/j.anireprosci.2009. 05.002)

Britt JH, Scott RG, Armstrong JD \& Whitacre MD 1986 Determinants of estrous behavior in lactating Holstein cows. Journal of Dairy Science 69 2195-2202. (doi:10.3168/jds.S0022-0302(86)80653-1)

Buhi WC 2002 Characterization and biological roles of oviduct-specific, oestrogen-dependent glycoprotein. Reproduction 123 355-362. (doi:10. 1530/rep.0.1230355)

Castro FC, Porcayo JO, Aké-López RJ, Magaña-Monforte GJ, Rubén C, Pérez M \& Segura JC 2013 Effect of body condition score on estrus and ovarian function characteristics of synchronized beef-master cows. Tropical and Subtropical Agroecosystems 16 193-199.

Chenault JR, Thatcher WW, Kalra PS, Abrams RM \& Wilcox CJ 1975 Transitory changes in plasma progestins, estradiol, and luteinizing hormone approaching ovulation in the bovine. Journal of Dairy Science 58 709-717. (doi:10.3168/jds.S0022-0302(75)84632-7)

Coe BL \& Allrich RD 1989 Relationship between endogenous estradiol and estrous behavior in heifers. Journal of Animal Science 67 1546-1551. (doi:10.2134/jas1989.6761546x) 
Cook DL, Winters TA, Horstman LA \& Allrich RD 1986 Induction of estrus in ovariectomized cows and heifers: effects of estradiol benzoate and gonadotropin releasing hormone. Journal of Animal Science 63 546-550. (doi:10.2134/jas1986.632546x)

Cummins SB, Lonergan P, Evans AC \& Butler ST 2012 Genetic merit for fertility traits in Holstein cows: II. Ovarian follicular and corpus luteum dynamics, reproductive hormones, and estrus behavior. Journal of Dairy Science 95 3698-3710. (doi:10.3168/jds.2011-4976)

Dadarwal D, Mapletoft RJ, Adams GP, Pfeifer LF, Creelman C \& Singh J 2013 Effect of progesterone concentration and duration of proestrus on fertility in beef cattle after fixed-time artificial insemination. Theriogenology 79 859-866. (doi:10.1016/j.theriogenology.2013.01.003)

Davidge ST, Wiebold JL, Senger PL \& Hillers JK 1987 Influence of varying levels of blood progesterone upon estrous behavior in cattle. Journal of Animal Science 64 126-132. (doi:10.2134/jas1987.641126x)

Demetrio DG, Santos RM, Demetrio CG \& Vasconcelos JL 2007 Factors affecting conception rates following artificial insemination or embryo transfer in lactating Holstein cows. Journal of Dairy Science $\mathbf{9 0}$ 5073-5082. (doi:10.3168/jds.2007-0223)

Dieleman SJ, Bevers MM, van Tol HTM \& Willemse AH 1986 Peripheral plasma concentrations of oestradiol, progesterone, cortisol, LH and prolactin during the oestrous cycle in the cow, with emphasis on the peri-oestrous period. Animal Reproduction Science 10 275-292. (doi:10.1016/0378-4320(86)90003-5)

Duchens M, Forsberg M, Edqvist LE, Gustafsson H \& RodríguezMartínez H 1994 Effect of induced suprabasal progesterone levels around estrus on plasma concentrations of progesterone, estradiol-17 $\beta$ and LH in heifers. Theriogenology 42 1159-1169. (doi:10.1016/0093691X(94)90864-8)

Edmondson AJ, Lean IJ, Weaver LD, Fervor T \& Webster G 1989 A body condition scoring chart for Holstein dairy cows. Journal of Dairy Science 72 68-78. (doi:10.3168/jds.S0022-0302(89)79081-0)

van Eerdenburg FJCM 2008 Possible causes for the diminished expression of estrus behavior. Veterinary Quarterly 30 (Suppl 1) 79-100.

Evans NP, Dahl GE, Padmanabhan V, Thrun LA \& Karsch FJ 1997 Estradiol requirements for induction and maintenance of the gonadotropinreleasing hormone surge: implications for neuroendocrine processing of the estradiol signal. Endocrinology 138 5408-5414. (doi:10.1210/ endo.138.12.5558)

Ferguson JD \& Galligan DT 1993 Prostaglandin synchronization programs in dairy herds (part I). Compendium on Continuing Education for the Practicing Veterinarian 15 646-655.

Glencross RG, Esselmont RJ, Bryant MJ \& Pope GS 1981 Relationship between the incidence of preovulatory behavior and the concentrations of oestradiol-17 $\beta$ and progesterone in bovine plasma. Applied Animal Ethology 7 141-148. (doi:10.1016/0304-3762(81)90092-4)

Jinks EM, Smith MF, Atkins JA, Pohler KG, Perry GA, MacNeil MD, Roberts AJ, Waterman RC, Alexander LJ \& Geary TW 2013 Preovulatory estradiol and the establishment and maintenance of pregnancy in suckled beef cows. Journal of Animal Science 91 1176-1185. (doi:10.2527/jas.2012-5611)

Kastelic JP \& Ginther OJ 1991 Factors affecting the origin of the ovulatory follicle in heifers with induced luteolysis. Animal Reproduction Science 26 13-24. (doi:10.1016/0378-4320(91)90062-5)

Katz LS, Oltenacu EA \& Foote RH 1980 The behavioral responses in ovariectomized cattle to either estradiol, testosterone, androstenedione or dihydrotestosterone. Hormones and Behavior 4 224-235. (doi:10.1016/0018-506X(80)90031-8)

King ME, Kiracofe GH, Stevenson JS \& Schalles RR 1982 Effect of stage of estrous cycle on interval to estrus after $\mathrm{PGF}_{2 \alpha}$ in beef cattle. Theriogenology 18 191-200. (doi:10.1016/0093-691X(82)90103-0)

Larson LL \& Ball PJ 1992 Regulation of estrous cycles in dairy cattle: a review. Theriogenology 38 255-267. (doi:10.1016/0093-691X(92) 90234-I)

Larsson B 1987 Determination of ovulation by ultrasound examination and its relation to the LH-peak in heifers. Journal of Veterinary Medicine. Series A 34 749-754. (doi:10.1111/j.1439-0442.1987.tb00342.x)

Law RA, Young FJ, Patterson DC, Kilpatrick DJ, Wylie AR \& Mayne CS 2009 Effect of dietary protein content on estrous behavior of dairy cows during early and mid lactation. Journal of Dairy Science 92 1013-1022. (doi:10.3168/jds.2008-1179)
Linares T, King WA \& Ploen L 1980 Observations on the early development of embryos from repeat breeder heifers. Nordisk Veterinaermedicin 32 433-443.

Lopez H, Satter LD \& Wiltbank MC 2004 Relationship between level of milk production and estrous behavior of lactating dairy cows. Animal Reproduction Science 81 209-223. (doi:10.1016/j.anireprosci.2003. 10.009)

López-Gatius F, Santolaria P, Yaniz J, Ruthant J \& Lopez-Bejar M 2001 Persistent ovarian follicles in dairy cows: a therapeutic approach. Theriogenology 56 649-659.

López-Gatius F, Lopez-Bejar M, Fenech M \& Hunter RH 2005a Ovulation failure and double ovulation in dairy cattle: risk factors and effects. Theriogenology 63 1298-1307. (doi:10.1016/j.theriogenology. 2004.06.010)

López-Gatius F, Santolaria P, Mundet I \& Yániz JL 2005b Walking activity at estrus and subsequent fertility in dairy cows. Theriogenology 63 1419-1429. (doi:10.1016/j.theriogenology.2004.07.007)

Lyimo ZC, Nielen M, Ouweltjes W, Kruip TA \& van Eerdenburg FJ 2000 Relationship among estradiol, cortisol and intensity of estrous behavior in dairy cattle. Theriogenology 53 1783-1795. (doi:10.1016/S0093691X(00)00314-9)

Mussard ML, Burke CR \& Day ML 2003a Ovarian follicle maturity at induced ovulation influences fertility in cattle. In Proceedings of the Annual Conference of the Society for Theriogenology. Columbus, $\mathrm{OH}$, pp 179-185.

Mussard ML, Burke CR, Gasser CL, Behlke EJ, Colliflower KA, Grum DE \& Day ML 2003b Ovulatory response, luteal function and fertility in cattle induced to ovulate dominant follicles of early or late maturity. Biology of Reproduction 68 (Suppl 1) 332 (Abstr. 535).

Mussard ML, Burke CR, Behlke EJ, Gasser CL \& Day ML 2007 Influence of premature induction of a luteinizing hormone surge with gonadotropin-releasing hormone on ovulation, luteal function and fertility in cattle. Journal of Animal Science 85 937-943. (doi:10.2527/jas. 2006-592)

Nebel RL, Dransfield MG, Jobst SM \& Bame JH 2000 Automated electronic systems for the detection of oestrus and timing of $\mathrm{Al}$ in cattle. Animal Reproduction Science 61 713-723. (doi:10.1016/S03784320(00)00090-7)

NRC 2001 Nutrient Requirements of Dairy Cattle, 7th rev. edn. Washington, DC: National Academy Press.

Ozturk S \& Demir R 2010 Particular functions of estrogen and progesterone in establishment of uterine receptivity and embryo implantation. Histology and Histopathology 25 1215-1228.

Perez-Marin CC \& Espana F 2007 Oestrus expression and ovarian function in repeat breeder cows, monitored by ultrasonography and progesterone assay. Reproduction in Domestic Animals 42 449-456. (doi:10.1111/j. 1439-0531.2006.00805.x)

Rajamahendran R, Robinson J, Desbottes S \& Walton JS 1989 Temporal relationships among estrus, body temperature, milk yield, progesterone and luteinizing hormone levels, and ovulation in dairy cows. Theriogenology 31 1173-1181. (doi:10.1016/0093-691X(89)90086-1)

Reames PS, Hatler TB, Hayes SH, Ray DL \& Silvia WJ 2011 Differential regulation of estrous behavior and luteinizing hormone secretion by estradiol-17 $\beta$ in ovariectomized dairy cows. Theriogenology $\mathbf{7 5}$ 233-240. (doi:10.1016/j.theriogenology.2010.08.009)

Ribadu AY \& Nakao T 1999 Bovine reproductive ultrasonography: a review. Journal of Reproduction and Development 45 13-28. (doi:10.1262/jrd. 45.13)

Ribeiro ES, Monteiro AP, Lima FS, Ayres H, Bisinotto RS, Favoreto M, Greco LF, Marsola RS, Thatcher WW \& Santos JE 2012 Effects of presynchronization and length of proestrus on fertility of grazing dairy cows subjected to a 5-day timed artificial insemination protocol. Journal of Dairy Science 95 2513-2522. (doi:10.3168/jds.2011-4921)

SAS 2002 User's Guide Version 9.2. Cary, NC, USA: SAS Institute, Inc.

Saumande J \& Humbolt P 2005 The variability in the interval between estrus and ovulation in cattle and its determinants. Animal Reproduction Science 85 171-182. (doi:10.1016/j.anireprosci.2003.09.009)

Schams D, Schallengerger E, Hoffmann B \& Karg H 1977 The oestrous cycle of the cow: hormonal parameters and time relationships concerning oestrus, ovulation and electrical resistance of the vaginal mucus. Acta Endocrinologica 86 180-192. (doi:10.1530/acta.0.0860180) 
Shore LS, Rios C, Marcus S, Bernstein M \& Shemesh M 1998 Relationship between peripheral estrogen concentrations at insemination and subsequent fetal loss in cattle. Theriogenology 50 101-107. (doi:10.1016/ S0093-691X(98)00117-4)

Short RE, Randel RD, Staigmiller RB \& Bellows RA 1979 Factors affecting estrogen-induced LH release in the cow. Biology of Reproduction $\mathbf{2 1}$ 683-689. (doi:10.1095/biolreprod21.3.683)

Singh B, Saravia F, Båge R \& Rodríguez-Martínez H 2005 Pregnancy rates in repeat-breeder heifers following multiple artificial inseminations during spontaneous oestrus. Acta Veterinaria Scandinavica 46 1-12. (doi:10.1186/1751-0147-46-1)

Stevenson JS, Schmidt MK \& Call EP 1983 Estrous intensity and conception rates in Holsteins. Journal of Dairy Science 66 275-280. (doi:10.3168/ jds.S0022-0302(83)81787-1)

Stevenson JS, Schmidt MK \& Call EP 1984 Stage of estrus cycle, time of insemination, and seasonal effects on estrous and fertility of Holstein heifers after prostaglandin $F_{2 \alpha}$. Journal of Dairy Science 67 1798-1805. (doi:10.3168/jds.S0022-0302(84)81507-6)

Stevenson JS, Lamb GC, Kobayashi Y \& Hoffman DP 1998 Luteolysis during two stages of the estrous cycle: subsequent endocrine profiles associated with radiotelemetrically detected estrus in heifers. Journal of Dairy Science 81 2897-2903. (doi:10.3168/jds.S00220302(98)75850-3)

Tanabe TY \& Hann RC 1984 Synchronized estrus and subsequent conception in dairy heifers treated with prostaglandin F2a. I. Influence of stage of cycle at treatment. Journal of Animal Science $\mathbf{5 8} 805-811$. (doi:10.2134/jas1984.584805x)

Twagiramungu H, Guilbault LA, Proulx JG, Villeneuve P \& Dufour JJ 1992 Influence of an agonist of gonadotropin-releasing hormone (buserelin) on estrus synchronization and fertility in beef cows. Journal of Animal Science 70 1904-1910.
Twagiramungu H, Guilbault LA \& Dufour JJ 1995 Synchronization of ovarian follicular waves with a gonadotropin-releasing hormone agonist to increase the precision of estrus in cattle: a review. Journal of Animal Science 73 3141-3151.

Waldmann A, Reksen O, Lanksverk K, Kommisrud E, Dahl E, Refsdal AO \& Ropstad E 2001 Progesterone concentrations in milk fat at first insemination - effects on non-return and repeat-breeding. Animal Reproduction Science 65 33-41. (doi:10.1016/S0378-4320(00)00227-X)

Walsh SW, Williams EJ \& Evans AC 2011 A review of the causes of poor fertility in high milk producing dairy cows. Animal Reproduction Science 123 127-138. (doi:10.1016/j.anireprosci.2010.12.001)

Watts TL \& Fuquay JW 1985 Response and fertility of dairy heifers following injection with prostaglandin F2a during early, middle or late diestrus. Theriogenology 23 655-661. (doi:10.1016/0093-691X(85)90199-2)

Wiltbank MC 1998 Improving reproductive efficiency in high producing dairy cattle. In Proceedings of the XX World Buiatrics Congress, Sydney, pp 571-582 Sydney, Australia: WBC.

Xu ZZ, Burton LJ \& Macmillan KL 1996 Reproductive performance of lactating dairy cows following oestrus synchronization regimens with $\mathrm{PGF}_{2 \alpha}$ and progesterone. Theriogenology 47 687-701. (doi:10.1016/ S0093-691X(97)00027-7)

Yániz JL, Santolaria P, Giribet A \& López-Gatius F 2006 Factors affecting walking activity at estrus during postpartum period and subsequent fertility in dairy cows. Theriogenology 66 1943-1950. (doi:10.1016/j. theriogenology.2006.05.013)

Received 13 November 2014

First decision 26 January 2015

Revised manuscript received 25 February 2015

Accepted 2 March 2015 